\title{
A NEW SPECIES OF WAORANIELLA (PSOCODEA: 'PSOCOPTERA': LACHESILLIDAE: EOLACHESILLINAE) FROM THE RESERVA FLORESTAL DUCKE, AMAZONAS, BRAZIL
}

\author{
Alfonso N. García Aldrete ${ }^{1}$ \& Edward L. Mockford ${ }^{2}$ \\ ${ }^{1}$ Departamento de Zoología, Instituto de Biología, Universidad Nacional Autónoma de México, \\ Apartado Postal 70-153,04510 México, D. F., MÉXICO \\ E-mail:anga@ibiologia.unam.mx \\ ${ }^{2}$ Department of Biological Sciences, Illinois State University, Campus Box 4120, Normal, Illinois, \\ 61790-4120, USA. \\ E-mail: elmockf@ilstu.edu
}

García Aldrete, A. N. and E. L. Mockford. A new species of Waoraniella (Psocodea: 'Psocoptera': Lachesillidae: Eolachesillinae) from the Reserva Florestal Ducke, Amazonas, Brazil. Acta Zool. Mex. (n. s.), 27(1): 123-127.

ABSTRACT. Waoraniella vidali $\mathrm{n}$. sp., the second species in the genus, is described and illustrated on the basis of a male from Amazonas, Brazil. The hypandrium and clunium are autapomorphic for the family. The phallosome is similar to that of Eolachesilla, and the character state "Forewing Rs-M joined by a crossvein" is found to appear in three genera of the subfamily Lachesillinae. Thus Waoraniella and Eolachesilla are close, and the genera of Graphocaeciliini stand apart in the subfamily.

Key words. Taxonomy, Amazonia, neotropics, Waoraniellini.

García Aldrete, A. N. y E. L. Mockford. Una nueva especie de Waoraniella (Psocodea: 'Psocoptera': Lachesillidae: Eolachesillinae) de la Reserva Forestal Ducke, Amazonas, Brasil. Acta Zool. Mex. (n. s.), 27(1): 123-127.

RESUMEN. Se describe aquí Waoraniella vidali $\mathrm{n}$. sp., la segunda especie en el género, con base en un macho colectado en Amazonas, Brasil. El hipandrio y el clunio son autapomórficos para la familia, mientras que el falosoma es similar al de Eolachesilla; el estado de carácter "Venas Rs-M del ala anterior unidas por una vena transversal", se encuentra en tres géneros de la subfamilia Lachesillinae. Waoraniella y Eolachesilla son cercanas, y los géneros de la tribu Graphocaeciliini constituyen un grupo aparte en la subfamilia.

Palabras clave. Taxonomía, Amazonia, neotrópico, Waoraniellini. 


\section{INTRODUCTION}

The genus Waoraniella García Aldrete, is known from two females collected in the Waorani Ethnic Reserve, in Napo, Ecuador (0³0'10' 'S: $\left.76^{\circ} 26^{\prime} 00^{\prime \prime} \mathrm{W}\right)$; they constitute the type series of W. erwini (Lachesillidae: Eolachesillinae: Waoraniellini) (García Aldrete 2006).

One single male, belonging in the subfamily Eolachesillinae (cf. Key to subfamilies of Lachesillidae, in García Aldrete 2006), was found in the Collection of Invertebrates of the Instituto Nacional de Pesquisas da Amazônia, in Manaus, Amazonas, Brazil, made available for study by Dr. José Albertino Rafael, researcher of that institution. This specimen was assigned to Waoraniella García Aldrete because it falls within the diagnoses of the tribe Waoraniellini and of the genus (e. g., with ocelli; epistomal sulcus developed only laterally, not present dorsally; lacinia bicuspid, with outer cusp bidentate; tarsi two segmented; Rs stem in forewing flexuous; Rs-M in forewing joined by a crossvein; fore- and hindwing membranes with abundant microtrichia; veins in basal half of forewing [except $\mathrm{Cu} 2$ ] with two rows of setae; areola postica small; pterostigma much broader posteriorly).

The character state "Forewing Rs-M joined by a crossvein" has appeared three other times in the family, in the Lachesillinae genera Hemicaecilius, Lachesilla and Nadleria. The specimen here dealt with can not, for obvious reasons, be assigned to any of those genera. This specimen is of considerable interest, as it provides information on the male sex of the genus, and because it was collected some $1900 \mathrm{~km} \mathrm{E} \mathrm{of}$ the type locality of $W$. erwini.

The specimen above is here described and illustrated as a new species, at the risk of creating a synonym with $W$. erwini, minimized, we believe, by the distance between the two collecting localities, and because the areola postica in the Brazilian specimen is distinctly higher and narrower than in the Ecuadorian specimens.

\section{MATERIAL AND METHODS}

One male specimen was available for study; color was recorded by placing it in $80 \%$ ethyl alcohol, under a dissecting microscope, illuminated with white cold light at $80 \mathrm{X}$. The specimen was dissected in $80 \%$ ethyl alcohol and its parts (head, right legs and wings, and genitalia) were mounted on a slide in Canada Balsam. Illustrations were made with a drawing tube, and measurements were taken with a filar micrometer and are stated in $\mu \mathrm{m}$. Abbreviations of body parts measured are as follows: FW and HW: lengths of right fore- and hind- wings, $\mathrm{F}, \mathrm{T}$, $\mathrm{t} 1$, and $\mathrm{t} 2$ : lengths of femur, tibia, and tarsomeres 1 and 2 of right hind leg, ctt 1 : number of ctenidia on t 1 of right hind leg, f1...fn: lengths of flagellomeres $1 . . . n$ of right antenna, IO, D and d: minimum distance between compound eyes, antero-posterior diameter, and transverse diameter of right compound eye respectively, in front view of head, PO: $d / D$. The male holotype 
will be deposited in the Collection of Invertebrates, Instituto Nacional de Pesquisas da Amâzonia, Manaus, Amazonas, Brazil.

Family Lachesillidae

Subfamily Eolachesillinae

Tribe Waoraniellini

Waoraniella vidali n. sp. (ð).

(Figs. 1-5)

Color. Ground color orange brown. Compound eyes black, ocelli hyaline, with ochre centripetal crescents. Wings with a dark orange hue. Abdomen with brown, transverse subcuticular rings, less pigmented ventrally.

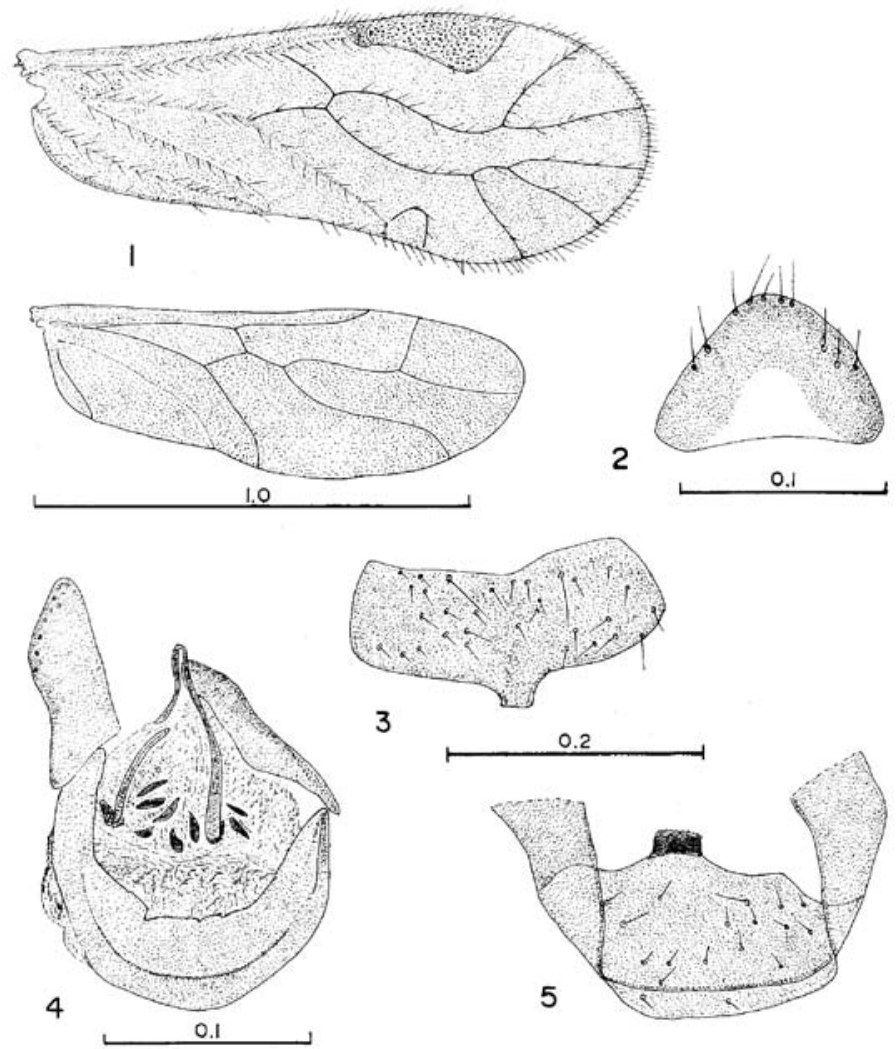

Figures 1-5. Structures of Waoraniella vidali n. sp. (ð). 1. Fore- and hind- wings. 2. Epiproct. 3. Hypandrium. 4. Phallosome. 5. Clunium. Scales in mm. Fig. 5 to scale of Fig. 3. 
Morphology. As in generic diagnosis (García Aldrete, 2006), plus the following: Five distal labral sensilla, in line, a central placoid, flanked by two trichoids. Pretarsal claw with a small pre-apical denticle, pulvillus broad. Wings (Fig. 1) as in generic diagnosis (cf. Introduction above and García Aldrete 2006). Hypandrium (Fig. 3) broad, setose, with a posterior truncate projection in the middle. Clunium (Fig. 5) projected posteriorly over the area of the epiproct to form a strongly sclerotized, almost rectangular extension, with the posterior edge straight, with small indentations. Phallosome (Fig. 4) closed anteriorly, with border rounded; aedeagal arch narrowing posteriorly; external parameres broad, blunt ended, with a row of pores on outer edge posteriorly; endophallus with nine small, elongate, spindle shaped sclerites. Epiproct (Fig. 2) broad, rounded posteriorly, with pigmented area deeply concave anteriorly, setae as illustrated. Paraprocts lost in preparation.

Measurements. FW: 1477, HW: 1129, F: 362, T: 614, t1: 212, t2: 88, ctt1: 13, f1: 193, f2: 159, IO: 289, D: 170, d: 78, IO/d: 3.7, PO: 0.45 .

Type locality. Brazil. Amazonas. Reserva Florestal Adolpho Ducke (030' $\mathrm{S}$ : $\left.60^{\circ} 02^{\prime} \mathrm{W}\right), 26 \mathrm{~km}$ NE Manaus, Rodovia AM 010. IX.2004. Malaise trap, Mata. Joao F. Vidal. Holotype $\widehat{\partial}$.

Etymology. This species is dedicated to Joao F. Vidal, for many years technician of the Collection of Invertebrates of the Instituto Nacional de Pesquisas da Amazônia (INPA), in recognition to his expertise and enthusiasm as insect collector of that Institution.

\section{DISCUSSION}

The description of $W$. vidali broadens the diagnosis of the genus (García Aldrete 2006) with the following male characters: Hypandrium with a truncate posterior projection in the middle. Clunium with a posterior rectangular projection over the area of the epiproct, the posterior edge of which presents small indentations. Phallosome closed anteriorly, external parameres broad, endophallus with small, spindle shaped sclerites.

The hypandrium and clunium of Waoraniella are autapomorphic, and the phallosome bears more resemblance to the phallosome of Eolachesilla (Eolachesillini), than to the phallosomes in the genera of Graphocaeciliini. In Waoraniella and Eolachesilla the phallosome is closed anteriorly, rounded; the external parameres are broad, distally blunt, and the endophallic sclerites are small, whereas in the genera of Graphocaeciliini, the phallosome is also closed anteriorly, but it is straight or extended anteriorly in the middle, the external parameres are often distally pointed, and the endophallus is compact, radula-like, or with large sclerites.

Considering the above, Waoraniella and Eolachesilla are close, and the genera of Graphocaeciliini (Graphocaecilius, Anomopsocus, Antilachesilla, Prolachesilla, Nanolachesilla, Tricholachesilla, Mesolachesilla, and Notolachesilla) stand apart in 
the subfamily. Presence of the character state "Forewing Rs-M joined by a crossvein" in the Lachesillinae genera Hemicaecilius, Lachesilla and Nadleria constitutes an independent event.

One of us (ELM), has found a female Waoraniella, that represents a species different from $W$. erwini, from Indiana, Peru, down river from Iquitos, in the area where the Napo and the Amazon rivers come together; this maintains Waoraniella as an endemic Amazonian genus.

ACKNOWLEDGMENTS. We are grateful to José Albertino Rafael (INPA, Manaus), for the loan of specimens of Psocoptera in the Collection of Invertebrates. We also thank Felipe Villegas (Instituto de Biología, UNAM), for his help with the plate of illustrations here included. ANGA thanks Instituto de Biología, UNAM., for supporting his research throughout the years.

\section{LITERATURE CITED}

García Aldrete, A. N. 2006. New genera of Psocoptera (Insecta), from Mexico, Belize and Ecuador (Psoquillidae, Ptiloneuridae, Lachesillidae). Zootaxa, 1319: 1-14.

Mockford, E. L. \& D. M. Sullivan. 1986. Systematics of the Graphocaeciliine psocids with a proposed higher classification of the family Lachesillidae (Psocoptera). Transactions of the American Entomological Society, 112: 1-80. 